\title{
Whole-tree dynamics of non-structural carbohydrate and nitrogen pools across different seasons and in response to girdling in two temperate trees
}

\author{
Li Mei · Yanmei Xiong · Jiacun Gu $\cdot$ Zhengquan Wang • \\ Dali Guo
}

Received: 31 March 2014 / Accepted: 8 December 2014 / Published online: 19 December 2014

(C) Springer-Verlag Berlin Heidelberg 2014

\begin{abstract}
Despite extensive research on the seasonal dynamics of non-structural carbohydrate (NSC) and nitrogen $(\mathrm{N})$ concentrations, the size and relative contributions of NSC and N pools across different tree organs are not well understood. We have measured the changes in NSC and $\mathrm{N}$ concentrations in leaves, branches, stems and all root branch orders at monthly intervals in control and girdled trees of larch (Larix gmelinii) and ash (Fraxinus mandshurica). The biomass of each plant compartment was also determined to calculate the size of the NSC and N pools. In both species, 13-37 \% of the NSC and N pools were mobilized at the beginning of the growing season. Among the mobilized pools, stems and non-absorptive roots (branch orders 4-9) acted as the largest NSC sources in larch and ash, respectively, while branches served as the largest $\mathrm{N}$ source in both species. After stem girdling, 22 and $50 \%$ of the root NSC stores in larch and ash, respectively, were
\end{abstract}

Communicated by Hermann Heilmeier.

\section{Mei}

Key Laboratory of Horticultural Plant Biology, Huazhong Agricultural University, Ministry of Education of China, Wuhan 430070, China

Y. Xiong $(\bowtie) \cdot$ D. Guo $(\bowtie)$

Qianyanzhou Ecological Station, Key Laboratory of Ecosystem

Network Observation and Modeling, Institute of Geographic

Sciences and Natural Resources Research, Chinese Academy

of Sciences, Beijing 100101, China

e-mail: xiongym@igsnrr.ac.cn

D. Guo

e-mail: guodl@igsnrr.ac.cn

J. Gu $\cdot$ Z. Wang

College of Forestry, Northeast Forestry University,

Harbin 150040, China mobilized to maintain root activities during the growing season. Tree mortality was observed 1 year after girdling, at which time there was still an abundant NSC pool in the roots. We conclude that (1) different storage organs differ in their contribution to new tissue growth at the beginning of the growing season and that those storage organs holding higher fractions of the NSC or N pool are not necessarily those which mobilize more NSC or N; (2) tree growth may not be limited by carbon (C) availability; (3) $\mathrm{C}$ storage in non-absorptive roots plays an important role in maintaining tree survival after the termination of photosynthate flow from aboveground sources.

Keywords C storage $\cdot \mathrm{N}$ storage $\cdot$ Source-sink relation · $\mathrm{C}$ limitation $\cdot$ Root branch order

\section{Introduction}

Trees store non-structural carbohydrates (NSC) and nitrogen $(\mathrm{N})$ in perennial structures when supply is greater than demand, and NSC and N stores have long been considered critical for the growth, physiology and functioning of plants (Chapin et al. 1990). These stores can make up the carbon (C) or $\mathrm{N}$ shortage when current demand exceeds supply due to the seasonality of plant growth (Chapin et al. 1990; Regier et al. 2010) or due to disturbances, such as shading (Kobe 1997), windthrow (Vargas et al. 2009) or herbivory (Kosola et al. 2001). The trunk, branches and coarse roots are the primary NSC and N reservoirs because these perennial structures constitute a large proportion of tree biomass (Sakai and Sakai 1998; Latt et al. 2001).

Mobilization and refilling of the NSC and N stores lead to fluctuations in these storage pools. The seasonal dynamics of NSC and N concentrations have been extensively 
studied in various plant species. In deciduous plants, when photosynthesis and $\mathrm{N}$ uptake are constrained by limited leaf area and low temperature in early spring, NSC and N are mobilized from the perennial structures to support tissue growth and respiration, resulting in decreased concentrations of NSC and N in these storage organs (Hoch et al. 2003; Palacio et al. 2007). After the growing season, particularly when tree growth ceases, storage pools are replenished and NSC and N concentrations increase (Landhäusser and Lieffers 2003; Teixeira et al. 2007). However, few studies have examined the sizes and dynamics of NSC and $\mathrm{N}$ pools at the whole-tree level and particularly those of roots, hindering a better understanding of the sink/source relationship and the role of different storage pools in plant functioning (Würth et al. 2005).

Roots are a key storage organ, and root $\mathrm{C}$ storage plays a vital role in maintaining plant physiology when trees suffer aboveground disturbance (Latt et al. 2001; Langley et al. 2002). For example, $C$ stores in woody roots were remobilized to maintain non-woody (lower branch order) absorptive roots after crown scorching that removed more than $80 \%$ of foliage (Guo et al. 2004) or after a fire that destroyed aboveground parts (Langley et al. 2002). Nevertheless, the extent of the mobilization of root $\mathrm{C}$ storage for root growth and maintenance has seldom been quantified. To fill this research gap, tree stem girdling may serve as a useful tool. Girdling removes the bark and phloem down to the youngest xylem and immediately terminates the flux of photosynthates from the tree canopy to the roots, while maintaining water transport in the reverse direction for possibly months (Högberg et al. 2001; Binkley et al. 2006). Once trees are girdled, roots can only use $\mathrm{C}$ reserves below the girdling cut (i.e. the basal part of the stem and the entire root system); consequently, girdling treatment provide the means to gain a quantitative understanding of the $\mathrm{C}$ costs in maintaining root functions by measuring the dynamics of root $\mathrm{C}$ storage pools in girdled trees.

Tree roots have a complex branching system with one to three distal non-woody branch orders devoted to resource uptake and several other woody root branch orders devoted to transport and long-term storage (Guo et al. 2008; Xia et al. 2010). Past studies documenting NSC and N dynamics in roots have not considered this branching architecture and have mostly separated root systems into coarse and fine roots based on root diameter (Latt et al. 2001; Würth et al. 2005; Kobe et al. 2010). However, this diameterbased approach may not accurately distinguish roots of different functions (absorptive roots vs. non-absorptive storage roots) (Pregitzer et al. 2002; Guo et al. 2004, 2008). To date, no published studies have reported NSC and N concentrations, pools and their seasonal dynamics across branch orders of the entire root system in mature trees.
In the study reported here we measured the biomass and seasonal dynamics of NSC and N concentrations in leaves, branches, stems and all root branch orders in two temperate deciduous trees to examine the relative roles of different storage organs in supplying $\mathrm{C}$ and $\mathrm{N}$ for new tissue growth at the beginning of the growing season. In addition, stem girdling was applied to examine the role of root $\mathrm{C}$ stores in maintaining root functioning after aboveground photosynthate supply was terminated. Larch (Larix gmelinii Rupr.) and ash (Fraxinus mandshurica Rupr.) were selected for girdling treatment because: (1) they are both dominant tree species in natural forests of Northeast China and are key plantation species, with larch representing $65 \%$ of conifer plantations and ash $10 \%$ of hardwood plantations (Wang et al. 2006); (2) the two species have different growth forms and growth strategies and thus may have different strategies of $\mathrm{C}$ and $\mathrm{N}$ storage (Gaucher et al. 2005). Larch is a fast-growing conifer, while ash is a broad-leaved species that grows more slowly. The northern temperate climate zone where these species are found is characterized by strong seasonality (Wang et al. 2006), thereby facilitating detection of the role(s) of different plant organs in supplying and refilling NSC and N over a growing season. Our specific hypotheses were: (1) in both species, seasonal dynamics of NSC and N concentrations will be similar despite the large differences in the pool size among different organs because of the similar seasonality of tree growth in the two species (both being deciduous and growing at the same site); (2) in both species, storage organs holding a larger proportion of tree NSC or N will mobilize more NSC or $\mathrm{N}$ for new tissue growth at the beginning of the growing season; (3) after stem girdling, NSC stores in nonabsorptive roots will be mobilized to maintain absorptive roots until depletion, and the species with a smaller belowground NSC store will show a greater decline of root NSC store in response to girdling.

\section{Materials and methods}

\section{Study site}

The experiment was conducted at Maoershan Forest Research Station $\left(45^{\circ} 21^{\prime}-45^{\circ} 25^{\prime} \mathrm{N}, 127^{\circ} 30^{\prime}-127^{\circ} 34^{\prime}\right.$ E), Northeast Forestry University, Heilongjiang, China. The site is subject to a continental temperate monsoon climate. Mean January, July and annual temperatures are $-19.6{ }^{\circ} \mathrm{C}$, $20.9^{\circ} \mathrm{C}$ and $2.8^{\circ} \mathrm{C}$, respectively. The growing season lasts from May to September and ranges from 120 to 140 days. Annual precipitation ranges between 700 and $800 \mathrm{~mm}$, with 75-80 \% occurring in June, July and August. Soils are Hap-Boric Luvisols, which vary from in depth from 30 to $>50 \mathrm{~cm}$, with high organic matter content $(14 \%$ in top $10 \mathrm{~cm}$ of soil layer) and good drainage. More details on 
the soil characteristics and site can be found in Wang et al. (2006).

Pure plantations of L. gmelinii (referred to as larch hereafter) and F. mandshurica (referred to as ash hereafter) were selected, both being established in 1986 with 2-yearold seedlings in a $1.5 \times 2.0$-m planting grid. In total, 3.6 ha of larch and 1.8 ha of ash were established in 1986. No fertilizers had been applied since planting. At the time of sampling in 2005 , tree spacing remained at $1.5 \times 2.0 \mathrm{~m}$ in the ash stand, but was about $3.0 \times 2.0 \mathrm{~m}$ in the larch stand due to self-thinning. In 2005, larch and ash had mean trunk diameters at breast height (DBH) of $11.4 \mathrm{~cm}$ [standard deviation (SD) 3.2, $n=300$ ] and $8.2 \mathrm{~cm}(\mathrm{SD} 2.3, n=300)$, respectively, and heights of $11.7 \mathrm{~m}(\mathrm{SD} 1.9, n=300)$ and $11.5 \mathrm{~m}(\mathrm{SD} 1.3, n=300)$, respectively.

\section{Girdling and sampling}

In early May 2005-before bud break-three replicate plots $(20 \times 30 \mathrm{~m})$ were randomly chosen in each plantation, and six randomly chosen trees were girdled on May 15 in each plot. Trees were girdled at $1.3 \mathrm{~m}$ above the ground by completely removing a $10 \mathrm{~cm}$ (in height) section of bark around the circumferences of the stems. Recovered callus following girdling was removed monthly. After girdling, much fewer leaves emerged from the girdled trees, and the leaves were smaller in size compared to those of the control trees (field observations). We did not collect data on root dynamics after girdling, but we observed that the fine roots in the girdled trees turned black after girdling and that a few new roots were produced from some root branches. The timing of leaf senescence leaf-fall did not differ between control trees and girdled trees. In the spring, no leaf emerged from girdled trees, and whole-tree mortality was confirmed in May 2006 (field observations).

Tissues of different organs were sampled six times (2005: May 15, June 15, July 15, August 15, September 15; 2006: May 20) over a 1- year period according to tree phenology. Bud break occurred between May 10 and May 20 of 2005, with larch showing bud break about 7 days earlier than ash. Complete leaf expansion occurred by May 30, and leaves started to turn yellow on September 10 in both trees. Leaves fell on September 20 in ash and 10 days later in larch. On each date, samples of leaves, branches, stems and intact root systems were collected from one girdled and one control tree in each plot, with different trees being sampled on different dates. Three branches (each with five branch orders) were sampled with pruning shears from the lower, middle and upper part of the crown. Leaves and branch-wood from these three branches were separated, and branch-wood from different branch cohorts were pooled together as mixed samples (referred to as "branches" hereafter). Stem samples were cored with an increment borer (diameter $7 \mathrm{~mm}$ ) at both the south-north and east-west orientations to the center of stems at a height above ground of $1.5 \mathrm{~m}$ (about $20 \mathrm{~cm}$ above the girdling cut), and the bark, sapwood and heartwood were combined as a mixed sample. The proportion of dead organs (bark and heartwood) in the whole stem cores was comparable between the two species. Bark thickness and heartwood diameter were 0.32 and $5.45 \mathrm{~cm}$, respectively, in larch (mean DBH $11.4 \mathrm{~cm}$ ) and 0.20 and $5.67 \mathrm{~cm}$, respectively, in ash (mean DBH $8.2 \mathrm{~cm}$ ). Root systems were sampled by manual excavation. A taproot was located, and all lateral roots attached to it were traced carefully with screw drivers, with careful removal of the soil around the roots to expose the intact root systems. This root sampling method was feasible because the soil in our site was rich in organic matter (14\%) and had a loose loam texture which eased the separation of roots from the soil; in addition, the roots had a relatively shallow distribution in the soil. The majority of roots were concentrated in the top $30 \mathrm{~cm}$ for larch and in the top $50 \mathrm{~cm}$ for ash (Wang et al. 2006). Roots of different branch orders were then sampled (Pregitzer et al. 2002). The entire root systems can be separated into nine branch orders in both species, with the distal root tip being the first order. In this study, the first to third branch orders were defined as absorptive roots (mean diameter $<0.5 \mathrm{~mm}$ ), and the forth to ninth branch orders were defined as non-absorptive roots (mean diameter $>0.5 \mathrm{~mm}$ ) based on the relationships between the diameter, anatomy and lifespan of different branch orders for the two species (Wang et al. 2006; Guo et al. 2008; Xia et al. 2010). After collection, all samples were immediately placed on dry ice, transported to the laboratory within $2 \mathrm{~h}$ and then killed in a microwave oven $(5 \mathrm{~min}$ at $800 \mathrm{~W}$, with a glass of water inside the oven to avoid overheating; Würth et al. 2005). Killed samples were washed with de-ionized water and dried in a convection oven at $65^{\circ} \mathrm{C}$ for $48 \mathrm{~h}$.

\section{Analyses of NSC and N concentrations}

All of the dried samples were ground into a fine powder and stored in plastic bottles before NSC and N concentrations were analyzed. Soluble sugar and starch concentrations were determined using with a modified phenol-sulphuric acid method (Buysse and Merckx 1993; Zhang et al. 2013). Briefly, a sub-sample was extracted overnight with $80 \%$ ethanol (v/v), followed by two centrifugations. The supernatant was measured for soluble sugar concentration with a spectrophotometer at $490 \mathrm{~nm}$ (model UV-PC01; Shimadzu Corp., Kyoto, Japan). The residue from the ethanol extraction was boiled in $3 \% \mathrm{HCl}(\mathrm{w} / \mathrm{w}, 0.08 \mathrm{~N})$ for $3 \mathrm{~h}$ to transform starch into soluble sugars and then filtrated. The sugar concentration in the filtrate was measured using a spectrophotometer, and starch concentration was calculated as the sugar concentration multiplied by 0.9 . NSC concentrations 
were calculated as the sum of soluble sugar and starch. Total $\mathrm{N}$ concentration was analyzed using an automatic Kjeldahl analyzer (model KT260; Foss Inc., Hillerød, Denmark). Briefly, a sub-sample was digested in $98 \% \mathrm{H}_{2} \mathrm{SO}_{4}$ (w/w) and $\mathrm{H}_{2} \mathrm{O}_{2}$ with $\mathrm{CuSO}_{4}$ and $\mathrm{K}_{2} \mathrm{SO}_{4}$ as catalysts, transforming $\mathrm{N}$ into $\left(\mathrm{NH}_{4}\right)_{2} \mathrm{SO}_{4}$. A $40 \% \mathrm{NaOH}$ solution (w/v) was then used to release $\mathrm{NH}_{3}$ from $\left(\mathrm{NH}_{4}\right)_{2} \mathrm{SO}_{4}$, and the released $\mathrm{NH}_{3}$ was absorbed with $1 \%$ boric acid and transformed into $\left(\mathrm{NH}_{4}\right)_{2} \mathrm{~B}_{4} \mathrm{O}_{7}$. A solution of $0.1 \mathrm{M} \mathrm{HCl}$ was used to titrate the concentration of $\left(\mathrm{NH}_{4}\right)_{2} \mathrm{~B}_{4} \mathrm{O}_{7}$.

\section{Evaluation of biomass and sizes of NSC and N pools}

Ten trees of each species with increasing DBH (range 5.7$16.6 \mathrm{~cm}$ for larch and $5.7-13 \mathrm{~cm}$ for ash) were randomly chosen from these plots, harvested and separated into stems, branches, leaves and coarse roots (diameter $>2 \mathrm{~mm}$, primarily the sixth to ninth orders) (Wang et al. 2006) in August to quantify tree allometry. Sub-samples of these plant parts were dried and weighed to quantify biomass. Roots were washed in tap water before measurement. During excavation of the coarse roots, the coarse root systems from each tree were traced carefully and dug out. Equations for the association between DBH and the biomass of different plant parts were established based on the measurements of ten harvested trees. The biomass of each plant part of un-harvested trees was obtained by inserting each tree's DBH into the established equations. Three intact lateral root systems were sampled from each of three individual trees of each species and the sixth to ninth root orders (coarse roots) were separated. The proportion of each root order in the total biomass of coarse roots was then estimated. The tree-level biomass of each root order from the sixth to ninth order was calculated by multiplying the treelevel coarse root biomass by the biomass proportion of each order. For estimating fine root biomass, we took eight soil cores (diameter $10 \mathrm{~cm}$ ) to a depth of $30 \mathrm{~cm}$ from each plot; we then separated out the first five root orders and measured the biomass of each root order on a basis of soil area. The tree-level biomass of fine roots was calculated by multiplying the biomass per square meter by the total area of a plot and then dividing the product by the number of trees in a plot.

Since we only measured biomass once (in August, the peak of the growing season), we assumed that the biomass of the storage organs (stems, branches and the fourth to ninth order roots) stayed constant over the 1-year study period, which was a reasonable assumption given the slow turnover rate of these organs. However, the biomass of leaves and of the first three root branch orders varied over the seasons, with leaf biomass varying from zero in winter to a maximum in August (Wang et al. 2006). Therefore, allocation of NSC and $\mathrm{N}$ pools among all organs was measured only in August, and the size of the NSC or N pool in each organ was calculated by multiplying its biomass by its N or NSC concentration in August. In addition, the sizes of the NSC and N pools in the storage organs in different seasons were calculated by multiplying their respective biomass by their respective $\mathrm{N}$ or NSC concentrations at each sampling time.

The seasonal dynamics of NSC and N pools in storage organs of un-girdled trees throughout the whole year (May 2005 to May 2006) were quantified by the changes of NSC and $\mathrm{N}$ pools during the early growing season (mid-May to mid-June), mid-growing season (mid-June to mid-September) and dormant season (mid-September to the next midMay). An increase in the pools indicated that the storage organ acted as a sink, and a decrease indicated that the storage organ acted as a source. The $\mathrm{C}$ cost in maintaining the root systems throughout the growing season was calculated as the change in the NSC pool in the non-absorptive roots of girdled trees from mid-May to mid-September in 2005.

\section{Statistical analyses}

The differences in total biomass and the biomass in each plant part between larch and ash were determined by Student's $t$ test. For each plant organ, a two-way (sample month and treatment as the two main factors) factorial analysis of variance was conducted to test the differences of NSC and N concentrations among sampling dates and between control and girdled trees.

\section{Results}

Species differences in biomass, NSC and N pools and their allocation among organs

The NSC pool at peak growth accounted for 13 and $17 \%$ of the total biomass in larch and ash, respectively. The biomass of the leaves, branches, stems and non-absorptive roots (fourth to ninth orders), respectively, in larch was 1.4- to 2.6fold higher than that of the respective organs in ash (Fig. 1a). The biomass of the absorptive roots (first three orders) did not differ between larch and ash (Fig. 1a, aa). The sizes of the NSC and N pools in larch were 1.5-fold higher than those in ash (Fig. 1b, c). The largest fractions of biomass and NSC pool were allocated to stems in both species (Fig. 1d, e), and the largest fraction of $\mathrm{N}$ was allocated to leaves in larch and to non-absorptive roots in ash (Fig. 1f).

Seasonal dynamics of NSC and N concentrations and pools among organs in un-girdled trees

The NSC concentrations in all of the organs of larch and ash, except for the sixth root order of larch and the ninth 
(a)

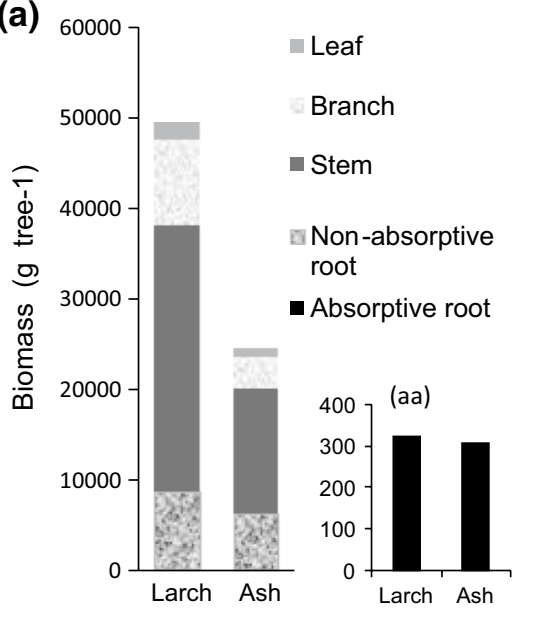

(d)

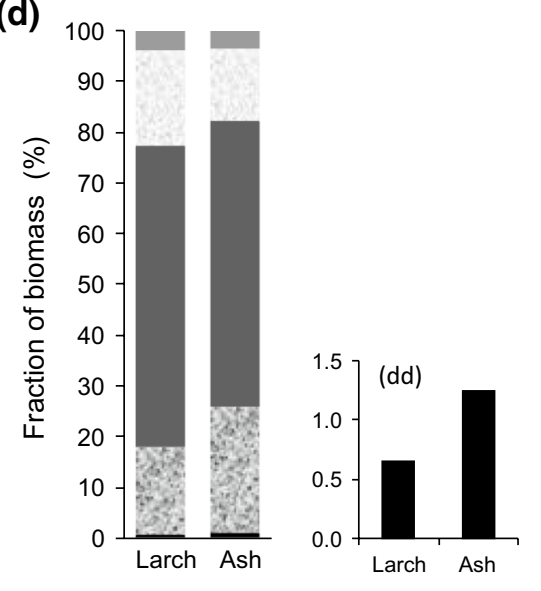

(b)
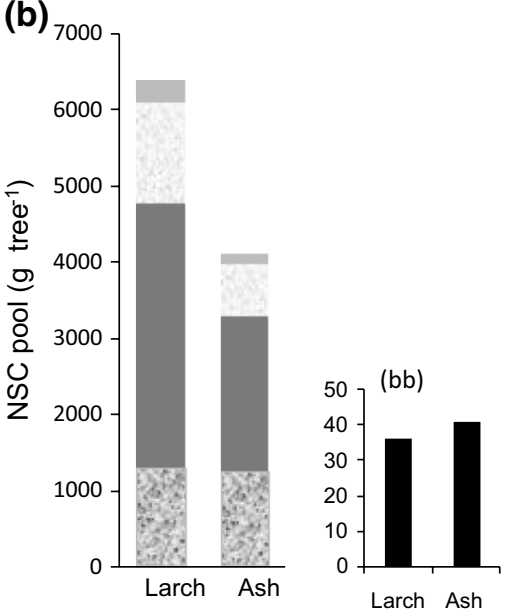

(e)

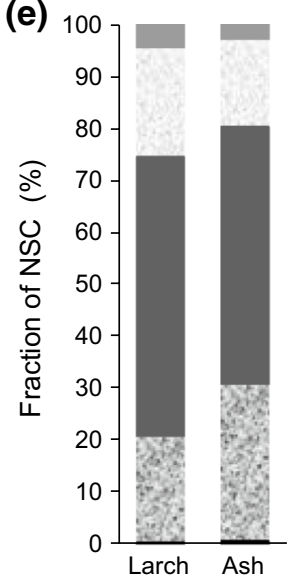

(c)

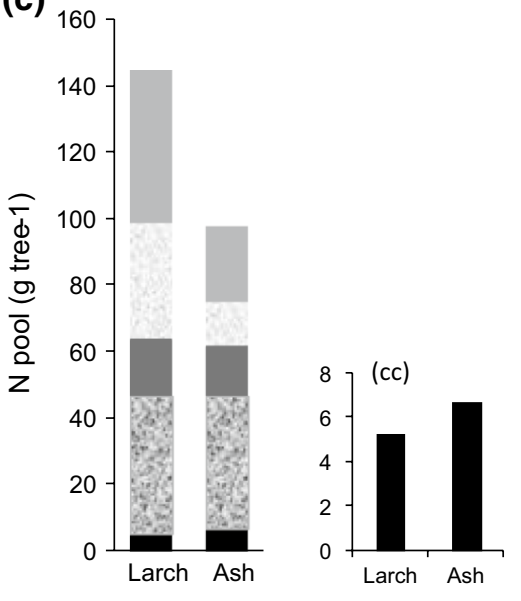

(f)

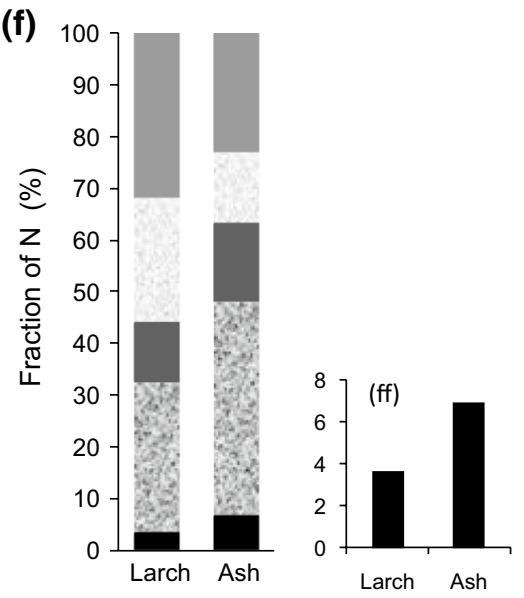

Fig. 1 Allocations of biomass $(\mathbf{a}, \mathbf{d})$ and of non-structural carbohydrate $(N S C ; \mathbf{b}, \mathbf{e})$ and nitrogen $(N ; \mathbf{c}, \mathbf{f})$ pools among organs of larch (Larix gmelinii) and ash (Fraxinus mandshurica) at the peak of the growing season (August). $n=24$ cores for each species for the first five root orders; for coarse roots and aboveground parts, the biomass of each plant part was obtained by inserting each tree's diameter at breast height $(\mathrm{DBH})$ into the biomass-DBH equations established by ten harvested trees for each species, and then averaged for all individuals in the plots. In each panel, data for absorptive roots are also shown in detail in a small panel because values were small compared to other plant parts $(a a, b b, c c, d d, e e, f f)$

4; Table 2). Leaf $\mathrm{N}$ concentration in both species decreased continuously from May to September (Fig. 2). In comparison $\mathrm{N}$ concentration in the branches and roots decreased from May to a minimum in June or July, following which it increased continuously until the end of the growing season. From September 15, 2005, to May 20, 2006 (the dormant season), $\mathrm{N}$ concentrations decreased in the higher order roots of larch while they increased in nearly all of the ash root orders (Fig. 4).

At the start of the growing season (from mid-May to mid-June), all storage organs (i.e. branches, stems and nonabsorptive roots) of ash and branches and stems of larch acted as NSC sources, with the largest source in larch and ash coming from stems and non-absorptive roots, respectively (Table 3). During this period, non-absorptive roots in larch acted only as a weak sink (Table 3). The NSC among sampling dates in both species $(P<0.05$; Figs. 2 , 
Fig. 2 Seasonal changes in NSC $(\mathbf{a}, \mathbf{b})$ and N (c, d) concentrations in aboveground organs of larch and ash. Data collected in 2005 (May to September; leaves and branches) and in 2005 and 2006 (May 2005 to May 2006; stems) are presented as the mean \pm standard error (SE) $(n=3)$. Asterisks indicate significant differences between control and girdling treatments for the respective organ at the $\alpha=0.05$ level

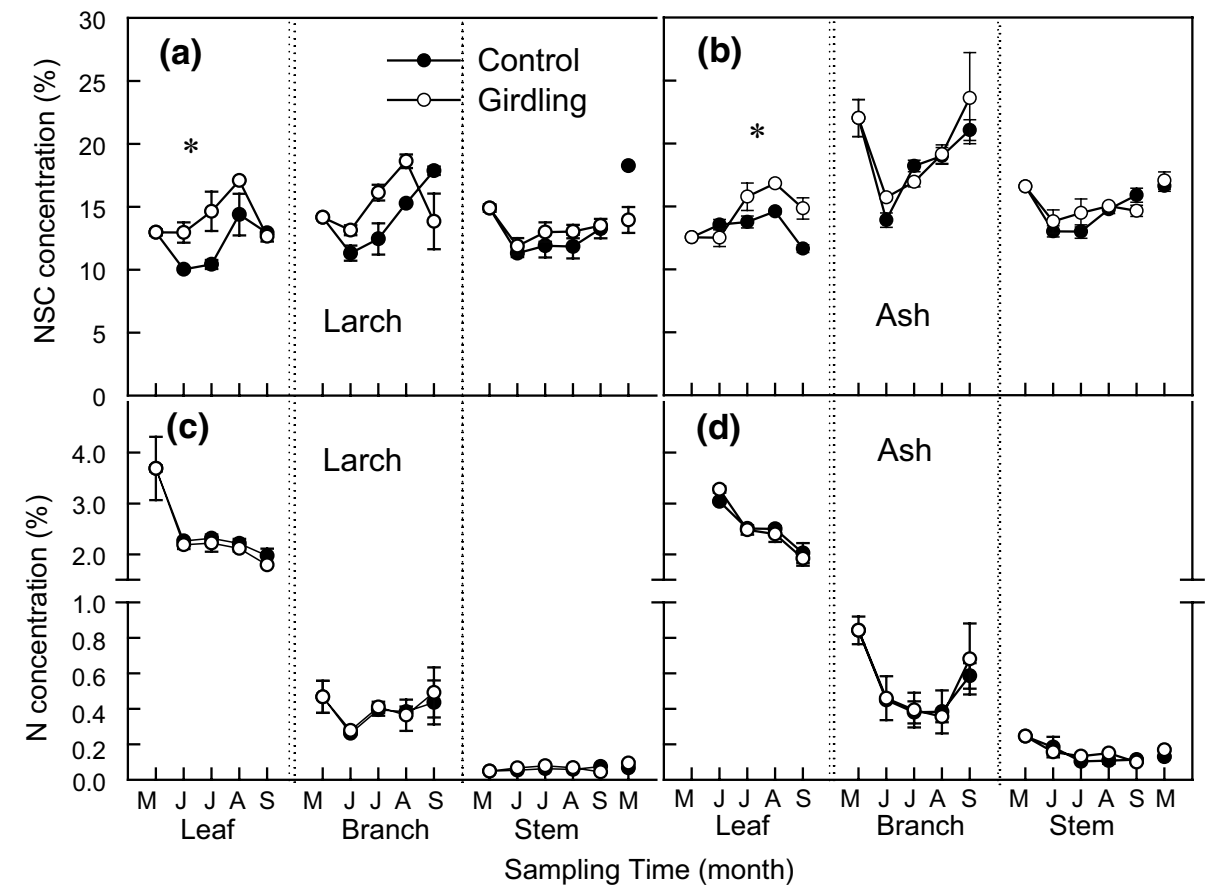

mobilized from storage organs for new tissue growth in this season accounted for 20 and $30 \%$ of whole-tree NSC storage in larch and ash, respectively. In the growing season (from mid-June to mid-September), all storage organs acted as NSC sinks, with the largest increase occurring in branches for larch and in non-absorptive roots for ash. During the dormant season (from mid-September until the next May), in both tree species non-absorptive roots served as a NSC source and stems served as a sink (Table 3).

During the early growing season, all storage organs of ash but only the branches of larch acted as N sources, while stems and non-absorptive roots of larch acted as weak sinks (Table 3). The $\mathrm{N}$ mobilized from storage organs for new tissue growth accounted for $13 \%$ of the $\mathrm{N}$ pool in larch and $37 \%$ in ash. During the growing season, all storage organs (stem, branch and non-absorptive roots) in larch and branches and non-absorptive roots in ash acted as $\mathrm{N}$ sinks, while stems in ash acted as a source. From mid-September until the next following May, stems and non-absorptive roots served as weak $\mathrm{N}$ sources in larch, but as weak $\mathrm{N}$ sinks in ash (Table 3).

\section{Carbon and nitrogen stores in response to stem girdling}

For both tree species, leaf NSC concentration was higher in girdled trees than in control trees $(P<0.05$ or 0.01 ; Fig. 2 ; Table 1). In contrast, NSC concentrations of all root orders of larch and non-absorptive roots of ash were lower in girdled trees than in control trees from 15 June onwards $(P<0.01$; Fig. 3; Table 1). NSC concentrations in branches and stems of both species and in absorptive roots of ash did not differ between girdled and control trees (Figs. 2, 3; Table 1). The seasonal variation in NSC concentration in most organs was similar in girdled and control trees for both species.

According to estimations based on the change in the size of the NSC pool in non-absorptive roots of girdled trees from mid-May to mid-September, the NSC cost in maintaining the root systems throughout the growing season amounted to 282 and $635 \mathrm{~g}$ per tree in larch and ash, respectively, accounting for 22 and $50 \%$ of the NSC pools in non-absorptive roots of larch and ash control trees, respectively, in August (data not shown).

$\mathrm{N}$ concentrations in all root orders of larch and in the first four root orders of ash were significantly lower in girdled trees than in control trees $(P<0.01$; Fig. 4; Table 2). For aboveground organs of both species and root orders 5-9 of ash, N concentration did not differ between girdled trees and control trees. The seasonal variation in $\mathrm{N}$ concentration in most organs of larch and in aboveground organs of ash was similar in girdled trees and control trees, with $\mathrm{N}$ concentration decreasing to a minimum, followed by a period of re-filling. However, for ash roots, $\mathrm{N}$ concentration decreased throughout the whole year after girdling and there was no re-filling (Fig. 4).

\section{Discussion}

Biomass, NSC pool and $\mathrm{N}$ pool and their allocation among organs

Despite the markedly different growth rates between larch and ash (indicated by total biomass per tree in Fig. 1), the 
two tree species had similar allocation patterns of biomass among organs. The largest fraction of biomass was allocated to stems, followed by branches and non-absorptive roots, with leaves and absorptive roots receiving the lowest fractions (Fig. 1). This allocation pattern is generally consistent with those reported from other tree studies (Würth et al. 2005; Zheng et al. 2006; Poorter et al. 2012). However, in shrubs and herbaceous plants, larger allocations to leaves or roots than stems have been reported, partly because of the different life forms of shrubs and herbs versus trees; moreover, allocation to leaves and roots tend to increase in smallsized plants (Palacio et al. 2007; Poorter et al. 2012).

Different allocation patterns of the NSC and N pools among organs may reflect their unique functions. In our study, the largest portion of the NSC pool was allocated in stems followed by branches and then non-absorptive roots (Fig. 1), as also shown in Würth et al. (2005). This pattern is consistent with the role of NSC as a C reserve and, therefore, its accumulation in storage organs. By contrast, leaves received either the largest or the second largest fraction of tree $\mathrm{N}$ (Fig. 1), consistent with reports that N-rich proteins (such as rubisco) in leaves constitute the various enzymes and components necessary for photosynthesis during the growing season (Evans 1989).

The size of the NSC pool reflects the balance between net photosynthetic C uptake (source) and investments in tissue construction and respiration (sink), and is thus commonly used to assess whether tree growth is C-limited (Körner 2003). Nevertheless, the sizes of the different NSC pools at the whole-tree level are not frequently reported in the literature due to the difficulties associated with complete root sampling. Our results show that the NSC pool accounted for 13 and $17 \%$ of the total biomass in our 20-year-old larch and ash trees, respectively, which is higher than the $8 \%$ reported for a whole tropical forest (Würth et al. 2005). The larger size of the older trees reported in the study of Würth et al. (2005) might partially explain this discrepancy. In larger trees the proportion of non-storage tissues (outer bark, heartwood) increases considerably in relation to storage tissues (living inner bark, sapwood; Magel et al. 1994, 2000); therefore, the NSC pool may account for a smaller portion of the total biomass in larger trees. Furthermore, larch and ash are deciduous trees growing in a temperate region, such that seasonality is distinct and likely to drive the trees to invest more in $\mathrm{C}$ storage compared to the tropical evergreens reported in Würth et al. (2005).

Seasonal dynamics of the sizes of NSC and N pools in different storage organs in control trees

The seasonal variation in NSC and N concentrations reflects their transfer among organs and a shifting role of 


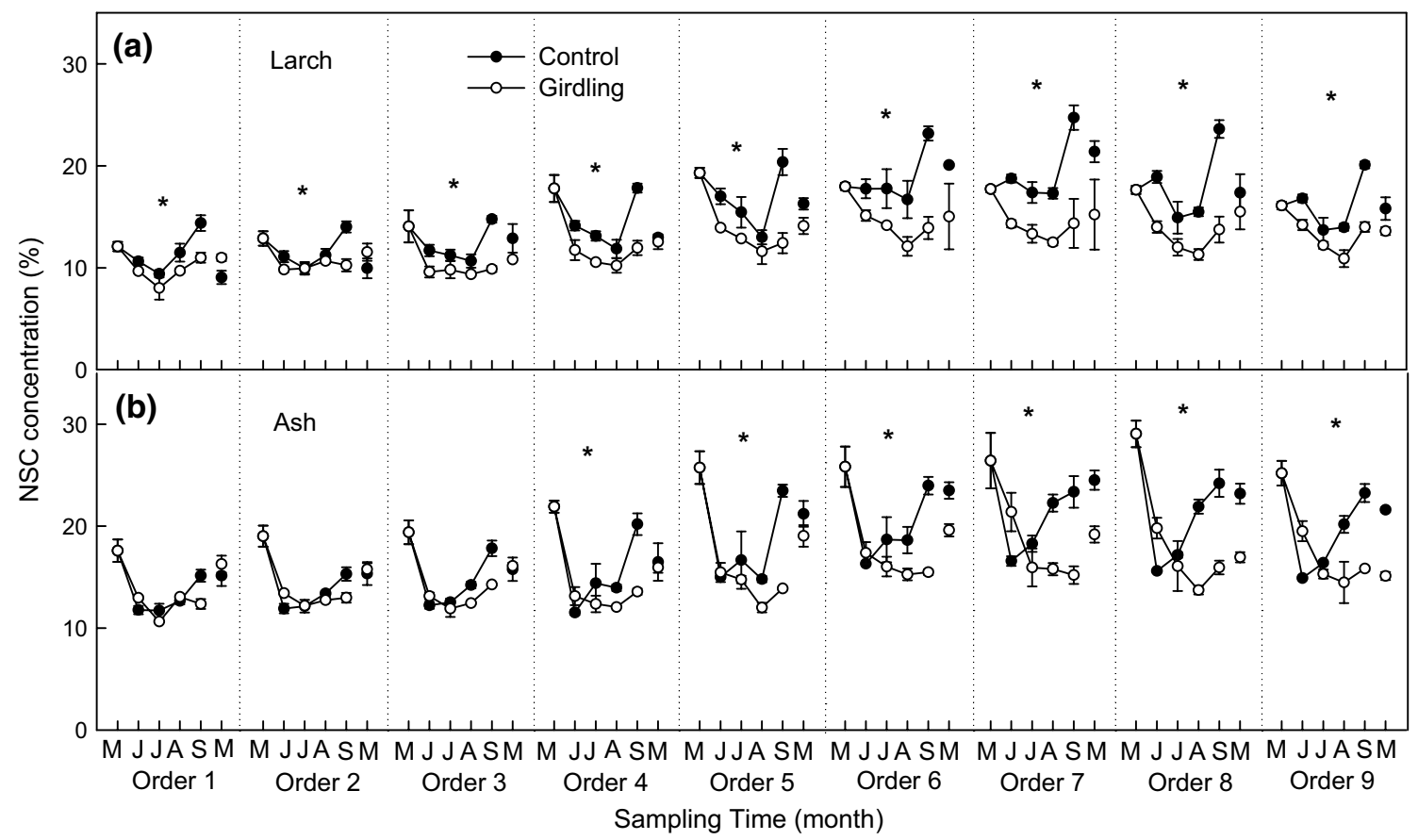

Fig. 3 Seasonal changes in NSC concentrations in different root branch orders (1-9) in larch (a) and ash (b). Data are presented as the mean $\pm \operatorname{SE}(n=3)$ during the sampling months from May 2005 to
May 2006. Asterisks indicate significant differences between control and girdling treatments for the respective root order at the $\alpha=0.05$ level

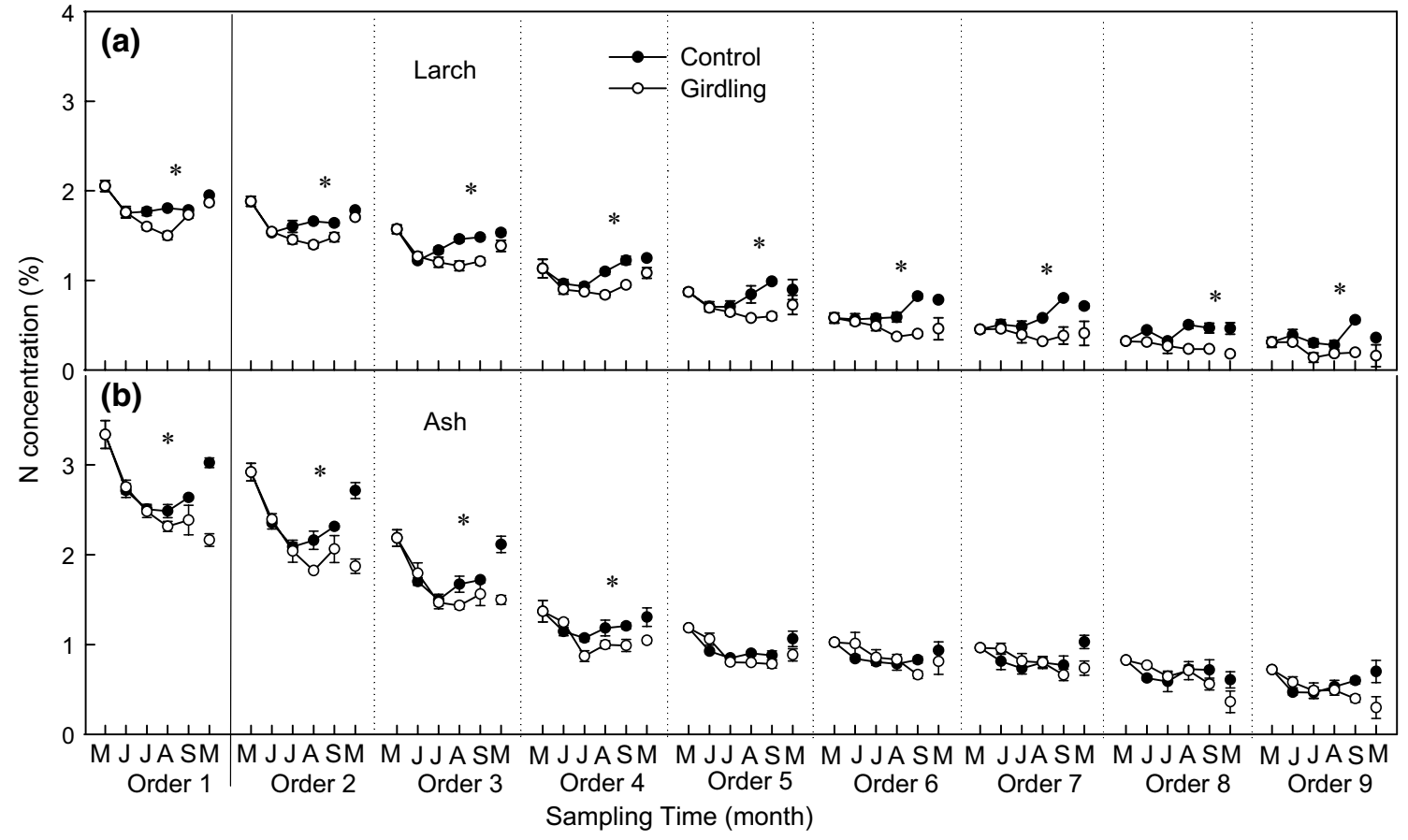

Fig. 4 Seasonal changes in $\mathrm{N}$ concentration in different root branch orders in larch (a) and ash (b). Data are presented as the mean \pm SE $(n=3)$ during the sampling months from May of 2005 to May of
2006. Asterisks indicate significant differences between control and girdling treatments for the respective root order at the $\alpha=0.05$ level 
the organs as either source or sink. NSC and N concentrations in storage organs typically decrease in springtime after bud flush and increase late in the growing season (Piispanen and Saranpää 2001; Gaucher et al. 2005; Spann et al. 2008). Correspondingly, the storage organs shift from being a source in the early growing season to becoming a sink in the late growing season (Palacio et al. 2007; Silpi et al. 2007). In our study, the seasonal variations in NSC and N concentrations in the storage organs were generally consistent with the reported pattern, thus supporting our first hypothesis that all organs showed similar seasonal dynamics despite the large differences in pool size. One exception was that in larch, NSC concentration increased from May to June in root branch orders of 7-9 and decreased from June to July or August in all root orders. This pattern may be partly explained by the bulk of root NSC in larch being used for fine-root and mycorrhizae respiration at the peak of the growing season (e.g. Jia et al. 2010), but not for producing new fine roots in the early growing season (therefore, NSC concentration in root orders of 7-9 in larch did not decrease from May to June as it did in other organs). Similar results have been reported for other coniferous ectomycorrhizal species which are heavily dependent on mycorrhizal fungi for resource uptake (Matamala et al. 2003; Lynch et al. 2013).

The extent to which $\mathrm{C}$ storage in storage organs is mobilized to support new tissue production and respiration at the start of the growing season has not yet been fully elucidated. Hoch et al. (2003) reported that the NSC pool in branches and stems in a temperate deciduous forest in Switzerland could rebuild the whole leaf canopy more than fourfold. Similarly, we calculated that the size of the NSC pool in branches + stems were 4.6- and sixfold greater than the $\mathrm{C}$ pools in the leaf canopy of larch and ash, respectively. However, the residence time of NSC storage could be several years, and only a small fraction of the NSC pool is likely to be mobilized during a growing season under normal conditions (Würth et al. 2005; Vargas et al. 2009; Richardson et al. 2013). In our study, the NSC mobilized from storage organs from mid-May to mid-June accounted for 20 and $31 \%$ of the whole-tree NSC pool in larch and ash, respectively, which are comparable to values (less than one-third) reported in other studies (Hoch et al. 2003; Würth et al. 2005; Körner 2003). Given that fluctuations in NSC pools across periods of varying $\mathrm{C}$ demand provide an indication of the $\mathrm{C}$ supply status of trees, the small portions of NSC pool mobilized for new tissue growth at the start of the growing season support the view that tree growth may not be limited by C availability (Körner 2003).

Moreover, the seasonal dynamics of NSC and N stores in the different organs also provided insights on the relative importance of different storage organs as sinks or sources. In the early growing season, a portion of NSC and 
Table 3 Seasonal non-structural carbohydrate and nitrogen dynamics in storage organs ${ }^{\mathrm{a}}$ in control trees

\begin{tabular}{|c|c|c|c|c|c|c|c|c|c|}
\hline \multirow[t]{2}{*}{ Pool } & \multicolumn{3}{|c|}{$\begin{array}{l}\text { Mid-May to mid-June (early growing } \\
\text { season) }\end{array}$} & \multicolumn{3}{|c|}{$\begin{array}{l}\text { Mid-June to mid-September (mid-growing } \\
\text { season) }\end{array}$} & \multicolumn{3}{|c|}{$\begin{array}{l}\text { Mid-September to following May (dor- } \\
\text { mancy season) }\end{array}$} \\
\hline & Branch & Stem & Non-absorptive root & Branch & Stem & Non-absorptive root & Branch & Stem & Non-absorptive root \\
\hline \multicolumn{10}{|c|}{ NSC pool $\left(g_{\text {tree }}^{-1}\right)$} \\
\hline Larch & 250 & 1,046 & -53.7 & -605 & -573 & -364 & ND & $-1,461$ & 410 \\
\hline Ash & 233 & 382 & 648 & -340 & -288 & -494 & ND & -102 & 67.7 \\
\hline \multicolumn{10}{|c|}{$\mathrm{N}$ pool $\left(\mathrm{g}_{\text {tree }}{ }^{-1}\right)$} \\
\hline Larch & 19.3 & -1.3 & -5.8 & -16.4 & -6.1 & -12.7 & ND & 2.1 & 7 \\
\hline Ash & 13.8 & 8.5 & 13.4 & -4.8 & 9.7 & -4.4 & ND & -2.2 & -5.2 \\
\hline
\end{tabular}

Positive values indicate sources (decreases) and negative values indicate sinks (increases)

ND, No data

a Storage organs: branches, stems and non-absorptive roots

$\mathrm{N}$ stores in storage organs should have been mobilized for the production or maintenance of cambium and new shoots and roots. In this regard, larch drew NSC and N only from aboveground organs, with stems acting as the largest source of NSC and branches as the largest source of N (Table 3). However, ash relied on non-absorptive roots as the largest source $(51 \%)$ of mobile NSC and on branches as the largest (39\%) of mobile $\mathrm{N}$ (Table 3). This result does not support our second hypothesis that storage organs holding higher fractions of NSC and N pools would contribute more to the mobilization of NSC and N for new tissue production or tissue maintenance in the early growing season. One explanation for this result is that among the storage organs (branches, stems and non-absorptive roots), both species allocated the largest fractions of the NSC pool to stems and the largest fractions of the $\mathrm{N}$ pool to non-absorptive roots (Fig. 1). During the dormant season, non-absorptive roots served as a NSC source while stems served as a sink in both species (Table 3). Other studies have shown that the activities of cambium, xylem and phloem cease during the dormant season in several temperate and sub-tropical trees (Venugopal and Liangkuwang 2007; Prislan et al. 2013). Therefore, the NSC transferred from non-absorptive roots to stems in the dormant season might be used for stem respiration instead of production.

\section{Response to girdling}

Stores of NSC and N in non-absorptive roots played important roles in maintaining root functions after the abrupt damage by girdling in our study, consistent with the notion that root storage is pivotal for tree survivorship (Kobe 1997; Canham et al. 1999). Girdling terminated photosynthate flux from the tree canopy to roots. To maintain absorption and transport functions, the root NSC pool was mobilized immediately, as supported by the reduced root NSC concentrations caused by girdling in both species (in all root orders of larch and in the fourth to ninth root orders of ash) (Fig. 3). Since root functions were maintained, water and N transport from roots to aboveground organs might have also proceeded after girdling; therefore, photosynthesis would have continued after the girdling. This was evidenced by the increased NSC concentration in girdled tree leaves (Fig. 2), consistent with similar reports of carbohydrate accumulation in stems in response to girdling (Regier et al. 2010). N concentrations in aboveground organs were not affected by girdling, whereas $\mathrm{N}$ concentrations in all orders of ash roots and the sixth to ninth orders of larch roots were reduced by girdling after mid-June without replenishment by $\mathrm{N}$ uptake (Figs. 2, 4), suggesting that root $\mathrm{N}$ storage was mobilized to maintain the $\mathrm{N}$ requirements of aboveground organs while $\mathrm{N}$ uptake in absorptive roots was impaired by girdling, similar to previous findings of the effects of canopy scorching on roots (Guo et al. 2004). Consistent with the latter part of our third hypothesis, inter-specific differences occurred in response to girdling. Concentrations of NSC and N decreased in all root orders of larch after girdling, yet NSC concentration decreased only in the fourth to ninth root orders, and $\mathrm{N}$ concentration decreased only in the first four root orders in ash (Figs. 3, 4). The fact that girdling only affected certain root orders in ash might be due to the higher allocation of NSC and N pools belowground in ash than in larch (Fig. 1), and thus root activities in ash were maintained for a longer time period.

Tree mortality after girdling in our study could not be explained by root $\mathrm{C}$ starvation because mortality was found even when stored $\mathrm{C}$ in non-absorptive roots was still abundant, with more than one-half of the NSC pool remaining (Fig. 3). This finding was contrary to part of our third hypothesis that root functions would be maintained until the root NSC pool was depleted. Unlike defoliation or persistent shade, which also cause the interruption of carbohydrate flow to roots (Guo et al. 2004; Gaucher et al. 2005) but may be buffered by large root NSC reserves, girdling 
represents a severe and permanent damage event. This is evident from the reduced number and size of leaves in both girdled larch and ash, followed by death 1 year after girdling. Nevertheless, the large fraction of NSC stores remaining in the dead girdled trees supports the view that much of the NSC accumulated by trees may represent sequestration, not storage, and thus cannot be utilized (Millard and Grelet 2010). Our study suggests that tree girdling may not be used to separate soil respiration into autotrophic or root respiration versus heterotrophic respirations. It has been assumed that girdling terminates aboveground $\mathrm{C}$ flux and thus eliminates autotrophic respiration (Binkley et al. 2006; Chen et al. 2010). However, our study shows that a substantial portion of the root NSC pool (22\% in larch and $50 \%$ in ash) was mobilized to maintain root activities after girdling, thus, it is important to consider root $\mathrm{C}$ storage when measuring soil heterotrophic respiration using the tree girdling method, as originally suggested by Högberg et al. (2001). Although larch had a larger root biomass than ash (Fig. 1), the amount of root NSC mobilized to maintain the root system in larch after girdling was only onehalf ( $282 \mathrm{~g}$ per tree) that in ash ( $635 \mathrm{~g}$ per tree). This result might be related to the much higher ash root $\mathrm{N}$ concentrations (Fig. 4), which is indicative of a higher respiration rate. A number of studies have shown that root respiration rate is strongly and positively related to root $\mathrm{N}$ concentration because $\mathrm{N}$-rich enzymes drive metabolic processes and, consequently, respiration (Atkinson et al. 2007; Reich et al. 2008; Burton et al. 2012). The respiration- $\mathrm{N}$ concentration relation was also found in larch and ash at our study site (Jia et al. 2011). The $\mathrm{C}$ cost in maintaining the root activities in control trees might be greater than that calculated from girdled trees because root $\mathrm{N}$ concentrations were higher in control trees than in girdled trees in both species (Fig. 4).

\section{Conclusion}

We found that different storage organs differed in their contribution to new tissue growth at the beginning of the growing season and that storage organs with higher fractions of NSC or N pool were not necessarily the ones mobilizing more NSC or N pool for new tissue growth. The large size of the NSC pool together with the small portion of the NSC pool mobilized at the beginning of the growing season suggest that tree growth may not be limited by $\mathrm{C}$ availability. The large portion (more than one-half) of the NSC pool remaining in non-absorptive roots after tree death suggests that $\mathrm{C}$ was sequestered and hence unavailable to plants or that $\mathrm{C}$ starvation may not have been the only reason of tree mortality after girdling. The substantial portion of root NSC (22\% in larch and $50 \%$ in ash) spent on maintaining root activities after girdling suggests that the $\mathrm{C}$ and $\mathrm{N}$ stores in non-absorptive roots played an important role in maintaining tree survival; moreover, it is important to consider root $\mathrm{C}$ storage in separating soil respiration into autotrophic and heterotrophic components when using the girdling method.

Acknowledgments We thank Drs. Shuxia Jia, Jianwei Shi and Shuiqiang Yu for assistance in the field and laboratory. Our sincere thanks are extended to Dr. Sean Bloszies for the editing that greatly improved the manuscript. This study was supported by Grants from the National Basic Research Program of China (973 Program, 2012CB416903), One-Hundred Talent Project of Chinese Academy of Sciences (no. KZZD-EW-TZ-11), and National Science Foundation of China (31021001, 31370627).

\section{References}

Atkinson LJ, Hellicar MA, Fitter AH, Atkin OK (2007) Impact of temperature on the relationship between respiration and nitrogen concentration in roots: an analysis of scaling relationships, $Q_{10}$ values and thermal acclimation ratios. New Phytol 173:110-120

Binkley D, Stape JL, Takahashi EN, Ryan MG (2006) Tree-girdling to separate root and heterotrophic respiration in two Eucalyptus stands in Brazil. Oecologia 148:447-454

Burton AJ, Jarvey JC, Jarvi MP, Zak DR, Pregitzer KS (2012) Chronic $\mathrm{N}$ deposition alters root respiration-tissue $\mathrm{N}$ relationship in northern hardwood forests. Global Change Biol 18:258-266

Buysse J, Merckx R (1993) An improved colorimetric method to quantify sugar content of plant tissue. J Exp Bot 44:1627-1629

Canham CD, Kobe RK, Latty EF, Chazdon RL (1999) Interspecific and intraspecific variation in tree seedling survival: effects of allocation to roots versus carbohydrate reserves. Oecologia 121:1-11

Chapin FS III, Schulze ED, Mooney HA (1990) The ecology and economics of storage in plants. Annu Rev Ecol Syst 21:423-447

Chen D, Zhang Y, Lin Y, Fu S (2010) Changes in belowground carbon in Acacia crassicarpa and Eucalyptus urophylla plantations after tree girdling. Plant Soil 326:123-135

Evans JR (1989) Photosynthesis and nitrogen relationships in leaves of $\mathrm{C}_{3}$ plants. Oecologia 78:9-19

Gaucher C, Gougeon S, Mauffette Y, Messier C (2005) Seasonal variation in biomass and carbohydrate partitioning of understory sugar maple (Acer saccharum) and yellow birch (Betula alleghaniensis) seedlings. Tree Physiol 25:93-100

Guo DL, Mitchell RJ, Hendricks JJ (2004) Fine root branch orders respond differentially to carbon source sink manipulations in a longleaf pine forest. Oecologia 140:450-457

Guo DL, Li H, Mitchell RJ, Han WX, Hendricks JJ, Fahey TJ, Hendrick RL (2008) Fine root heterogeneity by branch order: exploring the discrepancy in root turnover estimates between minirhizotron and carbon isotopic methods. New Phytol 177:443-456

Hoch G, Richter A, Körner C (2003) Non-structural carbon compounds in temperate forest trees. Plant Cell Environ 26:1067-1081

Högberg P, Nordgren A, Buchmann N, Taylor AFS, Ekblad A, Högberg MN, Nyberg G, Ottosson-Löfvenius M, Read DJ (2001) Large-scale forest girdling shows that current photosynthesis drives soil respiration. Nature 411:789-792

Jia S, Wang Z, Li X, Sun Y, Zhang X, Liang A (2010) N fertilization affects on soil respiration, microbial biomass and root respiration in Larix gmelinii and Fraxinus mandshurica plantations in China. Plant Soil 333:325-336 
Jia S, Wang Z, Li X, Zhang X, Mclaughlin NB (2011) Effect of nitrogen fertilizer, root branch order and temperature on respiration and tissue $\mathrm{N}$ concentration of fine roots in Larix gmelinii and Fraxinus mandshurica. Tree Physiol 31:718-726

Kobe RK (1997) Carbohydrate allocation to storage as a basis of interspecific variation in sapling survivorship and growth. Oikos 80:226-233

Kobe RK, Iyer M, Walters MB (2010) Optimal partitioning theory revisited: nonstructural carbohydrates dominate root mass responses to nitrogen. Ecology 91:166-179

Körner C (2003) Carbon limitation in trees. J Ecol 91:4-14

Kosola KR, Dickmann DI, Paul EA, Parry D (2001) Repeated insect defoliation effects on growth, nitrogen acquisition, carbohydrate, and root demography of poplars. Oecologia 129:65-74

Landhäusser SM, Lieffers VJ (2003) Seasonal changes in carbohydrate reserves in mature northern Populus tremuloides clones. Trees Struct Funct 17:471-476

Langley JA, Drake BG, Hungate BA (2002) Extensive belowground carbon storage supports roots and mycorrhizae in regenerating scrub oaks. Oecologia 131:542-548

Latt CR, Nair PKR, Kang BT (2001) Reserve carbohydrate levels in the boles and structural roots of five multipurpose tree species in a seasonally dry tropical climate. For Ecol Manag 146:145-158

Lynch DJ, Matamala R, Iversen CM, Norby RJ, Gonzalez-Meler MA (2013) Stored carbon partly fuels fine-root respiration but is not used for production of new fine roots. New Phytol 199:420-430

Magel E, Jay-Allemand C, Ziegler H (1994) Formation of heart-wood substances in the stemwood of Robinia pseudoacacia L. II. Distribution of nonstructural carbohydrates and wood extrac-tives across the trunk. Trees 8:165-171

Magel E, Einig W, Hampp R (2000) Carbohydrates in trees. Develop. Crop Sci 26:317-336

Matamala R, Gonzalez-Meler MA, Jastrow JD, Norby RJ, Schlesinger WH (2003) Impacts of fine root turnover on forest NPP and soil C sequestration potential. Science 302:1385-1387

Millard P, Grelet GA (2010) Nitrogen storage and remobilization by trees: ecophysiological relevance in a changing world. Tree Physiol 30:1083-1089

Palacio S, Millard P, Maestro M, Montserrat-Marti G (2007) Nonstructural carbohydrates and nitrogen dynamics in Mediterranean sub-shrubs: an analysis of the functional role of over wintering leaves. Plant Biol 9:49-58

Piispanen R, Saranpää P (2001) Variation of non-structural carbohydrates in silver birch (Betula pendula Roth) wood. Trees Struct Funct 15:444-451

Poorter H, Niklas KJ, Reich PB, Oleksyn J, Poot P, Mommer L (2012) Biomass allocation to leaves, stems and roots: meta-analyses of interspecific variation and environmental control. New Phytol 193:30-50

Pregitzer KS, DeForest JL, Burton AJ, Allen MF, Ruess RW, Hendrick RL (2002) Fine root architecture of nine North American trees. Ecol Monogr 72:293-309
Prislan P, Gričar J, de Luis M, Smith KT, Čufar K (2013) Phenological variation in xylem and phloem formation in Fagus sylvatica from two contrasting sites. Agric For Meteorol 180:142-151

Regier N, Streb S, Zeeman SC, Frey B (2010) Seasonal changes in starch and sugar content of poplar (Populus deltoides $\times$ nigra $\mathrm{cv}$. Dorskamp) and the impact of stem girdling on carbohydrate allocation to roots. Tree Physiol 30:979-987

Reich PB, Tjoelker MG, Pregitzer KS, Wright IJ, Oleksyn J, Machado JL (2008) Scaling of respiration to nitrogen in leaves, stems and roots of higher land plants. Ecol Lett 11:793-801

Richardson AD, Carbone MS, Keenan TF, Czimczik CI, Hollinger DY, Murakami P, Schaberg PG, Xu X (2013) Seasonal dynamics and age of stemwood nonstructural carbohydrates in temperate forest trees. New Phytol 197:850-861

Sakai A, Sakai S (1998) A test for the resource remobilization hypothesis: tree sprouting using carbohydrates from above-ground parts. Ann Bot 82:213-216

Silpi U, Lacointe A, Kasempsap P, Thanysawanyangkura S, Chantuma P, Gohet E, Musigamart N, Clement A, Ameglio T, Thaler P (2007) Carbohydrate reserves as a competing sink: evidence from tapping rubber trees. Tree Physiol 27:881-889

Spann TM, Beede RH, Dejong TM (2008) Seasonal carbohydrate storage and mobilization in bearing and non-bearing pistachio (Pistacia vera) trees. Tree Physiol 28:207-213

Teixeira EI, Mott DJ, Mickelbart MV (2007) Seasonal patterns of root $\mathrm{C}$ and $\mathrm{N}$ reserves of lucerne crops (Medicago sativa $\mathrm{L}$.) grown in a temperate climate were affected by defoliation regime. Eur J Agron 26:10-20

Vargas R, Trumbore SE, Allen MF (2009) Evidence of old carbon used to grow new fine roots in a tropical forest. New Phytol 182(3):710-718

Venugopal N, Liangkuwang MG (2007) Cambial activity and annual rhythm of xylem production of elephant apple tree (Dillenia indica Linn.) in relation to phenology and climatic factor growing in sub-tropical wet forest of northeast India. Trees 21:101-110

Wang ZQ, Guo DL, Wang XR, Gu JC, Mei L (2006) Fine root architecture, morphology and biomass of different branch orders of two Chinese temperate tree species. Plant Soil 288:155-171

Würth MKR, Peláez-Riedl S, Wright SJ, Körner C (2005) Non-structural carbohydrate pools in a tropical forest. Oecologia 143:11-24

Xia MX, Guo DL, Pregitzer KS (2010) Ephemeral root modules in Fraxinus mandshurica. New Phytol 188:1065-1074

Zhang KM, Li Z, Li Y, Li YH, Kong DZ, Wu RH (2013) Carbohydrate accumulation may be the proximate trigger of anthocyanin biosynthesis under autumn conditions in Begonia semperflorens. Plant Biol 15:991-1000

Zheng Z, Feng Z, Cao M, Li Z, Zhang J (2006) Forest structure and biomass of a tropical seasonal rain forest in Xishuangbanna, Southwest China. Biotropica 38:318-327 